\title{
12 THE CHOICE OF CRITICAL INFORMATION SYSTEMS RESEARCH
}

\author{
Debra Howcroft \\ Manchester University \\ Eileen M. Trauth \\ Pennsylvania State University
}

\begin{abstract}
Accompanying the development and diffusion of information technologies throughout organizations and society is the research challenge to examine the relationship between information systems and the organizations and societies within which they are embedded. As the field of information systems matures, it is fitting that consideration be given to the ways in which such an examination is carried out. Thus, there is a research need not only to examine and assess the ways in which information systems are used and affect people; there is also a research need to examine and assess the research approaches that are used to carry out these assessments. This paper examines the enactment of the critical tradition in IS research and the possibilities for new insights that can arise from shifting the lens from positivist or interpretive to critical. This consideration leads to a discussion of issues that arise from the choice of critical IS research, followed by some recommendations for addressing these issues.
\end{abstract}

Keywords: Critical theory, critical management studies, critical information systems, gender, information systems development, research methods, information systems research

\section{INTRODUCTION}

Accompanying the development and diffusion of information technologies throughout organizations and society is the research challenge to examine the relationship between information systems and the organizations and societies within which they are embedded. Consideration should also be given to the ways in which such an examination is carried out. Thus, there are two research needs: (1) to examine and 
assess the ways in which information systems are used and affect people; and (2) to examine and assess the research approaches that are used to carry out these assessments. This recognition is reflected in the number of research papers, books, and conferences devoted to the topic of research approaches in IS. This paper contributes to this literature by considering the contribution and effect of employing a particular research tradition-the critical tradition-in the conduct of information systems research.

The paper is structured in the following way. Following a review of the critical tradition in social science research and its enactment in IS research to date, we consider the new insights that can arise from shifting the lens from the positivist or the interpretive to the critical. This consideration leads to a discussion of issues that arise from the choice of critical IS research and some recommendations for addressing them.

\section{WHAT IS A CRITICAL EPISTEMOLOGY?}

In the social sciences the term critical is used describe a range of related approaches, including critical theory (Horkheimer 1976), critical operational research (Mingers 1992), critical accounting (critical perspectives on accounting), critical ethnography (Forester 1992), and critical management studies (Alvesson and Willmott 1996). Each of these is subject to its own disciplinary connotations (Mingers 2000). However, a commonality across all of them is their dependence upon the critical theory of the Frankfurt School (Hammersley 1995).

Yet, despite some areas of commonality, there are some fairly distinct styles in the way research is performed (geographically, institutionally, and disciplinarily), resulting in a diversity of intellectual activity, some of which is indeed oppositional (e.g., realism vs. relativism, class politics vs. gender politics). Hence, there exists a broad range of epistemological/ontological positions, which fall under the critical umbrella, and which draw upon a variety of social theories and social thinkers. These include, for example, the Frankfurt School of critical theory (Horkheimer 1976), actor-network theory (Latour 1991), Marxism (Marx 1974), feminist theory (Wajcman 1991), and the work of Bourdieu (1990), Dooyeweerd (1973), Foucault (1979), and Heidegger (1953).

In contrast to the diversity within the social sciences, information systems research has been dominated by the Frankfurt School generally (Brooke 2002a), and more particularly, the work of Habermas (Doolin and Lowe 2002), with a core of authors committed to this area (Cecez-Kecmanovic 2001; Cecez-Kecmanovic et al. 1999; Hirschheim and Klein 1994; Klein and Hirschheim 1993; Lyytinen 1992; Lyytinen and Hirschheim 1988, 1989; Lyytinen and Klein 1985; Ngwenyama 1991; Ngwenyama and Lee 1997). Some have argued that the relative dominance of the Habermasian approach is unnecessarily limiting (Doolin and Lowe 2002) and have called for enrolling other critical social theorists whose work could be of relevance to IS (Brooke 2002b).

In order to outline a critical epistemology, we will draw upon five key themes emanating from the critical management studies (CMS) literature and resonating with IS research. The first theme, emancipation (Alvesson and Willmott 1992), is fundamental in a range of intellectual traditions be it Habermasian, feminist, or Marxist research. A thread running through all of these perspectives is a commitment to freeing individuals 
from power relations around which social and organizational life are woven (Fournier and Grey 2000). The objective is to focus on "the oppositions, conflicts and contradictions in contemporary society, and seeks to be emancipatory; that is, it should help to eliminate the causes of alienation and domination" (Myers and Avison 2002, p. 7).

The second theme, critique of tradition, seeks to disrupt rather than reproduce the status quo. Whereas traditional accounts seek to justify organizational and technological imperatives as natural and/or unavoidable, CMS challenges rather than confirms that which is established and encourages dissent rather than accepting surface consensus. This critique of tradition (Mingers 2000) endeavors to upset existing patterns of power and authority. Critical research questions and deconstructs the taken-for-granted assumptions inherent in the status quo, and interprets organizational activity (including information systems) by recourse to a wider social, political, historical, economic, and ideological context (Doolin 1998).

The third theme, non-performative intent (Fournier and Grey 2000), concerns the rejection of the provision of tools to support and assist managerial efficiency through reengineering minimum inputs for maximum outputs. This stands in contrast to nonCMS research, which aims to develop knowledge that contributes to the production of maximum output for minimum input (means-ends calculation). Similar claims are made on behalf of technology in general and information systems in particular, which are seen as augmenting the power of managerial decision-making.

The fourth theme, critique of technological determinism, challenges the discourse surrounding socio-economic change- be it post-industrial society, information society, or globalization (Avgerou 2002) - which assumes that technological development is autonomous and that societal development is determined by the technology (Bijker 1995). It disrupts the inner logic of technology as a given, something that is assumed to provide an effective and reliable vehicle for social and organizational change (Williams and Edge 1996). Critique of the technological determinist tradition highlights both its explanatory inadequacy and its ideological function of furthering the vested interests in technical change (Russell and Williams 2002).

The final theme, reflexivity, highlights a methodological distinction between critical management research and other management research. Whereas mainstream management studies are positivistic, critical management research engages in a critique of objectivity (Mingers 2000) which questions the validity of objective, value-free knowledge and information that is available, noting how this is often shaped by structures of power and interests. Like interpretive research, critical research engages in philosophical and methodological reflexivity (Fournier and Grey 2000).

\section{EMPLOYING A CRITICAL APPROACH IN IS RESEARCH}

It can be argued that the social nature of activities associated with the development, implementation, and use of IS and the management of people who carry out these activities leads naturally to considerations of social and political power. This consideration of power, in turn, encourages critical analysis (e.g., Beath and Orlikowski 1994; Franz and Robey 1984; Markus 1983). Yet even though there is a body of IS research 
concerned with issues of power and politics, it has not necessarily been identified as critical IS. Nevertheless, there has been a considerable shift in the research landscape since the publication of the seminal paper by Orlikowski and Baroudi (1991) which noted the dearth of critical IS research. While the end of the $20^{\text {th }}$ century witnessed the gradual emergence of a critical stream in IS research, albeit generally in the Habermasian tradition, the last few years has seen the effort to focus more explicit attention on critical perspectives. This is evidenced in an increasing number of publications, conference streams, special issues, and academic electronic networks concerned with discussing critical IS. Continuing in that vein, the discussion below considers alternative insights into the assessment of information systems uses and impacts that can arise from critical IS research. Just as Trauth and Jessup (2000) showed that different results emerge from an assessment of IT when the lens shifts from positivist to interpretive, we show how further insights can result from shifting the lens to critical.

\subsection{Critical Examination of Information Systems Development}

The area of information systems development (ISD) is vast and so this section will briefly highlight some of the differences in the various epistemological perspectives. The positivist epistemology characterizes systems development as one of rationality whereby actions are justified on rational grounds and the appropriate organizational rituals are adhered to (Boland and Pondy 1983). Such a perspective adopts a unitary model of organizations and is based on the assumption that information systems are designed to contribute to specific ends, ends that can be articulated, are shared, and are objective. Once built and installed, the system, itself an "icon of rationality" (Franz and Robey 1984), will improve the efficiency or effectiveness of decision-making processes, thus supporting managerial practices. IS developers are seen as systems experts (Hirschheim and Klein 1989), rational thinkers whose profession is based on their ability to solve abstract, complex problems, with computers being programmed to solve their problems. The tools and methodologies associated with this process also possess an aura of rationality, often based on mathematical and logical processing techniques as opposed to reliance on human intuition, judgement, and politics. The construction of the information system represents the mapping of organizational reality onto a more concrete machine-oriented level, and this process oftranslation is seen as enabling organizational reengineering or transformation. When performing these translations, developers are expected to follow structured techniques, which, in a Tayloristic fashion, facilitate the division of labor, provide an audit trail, and produce a so-called maintainable system. The resultant information system is thus seen as the "embodiment of rationality" (Newman 1989).

Emerging as a reaction to the shortcomings of the positivist paradigm and its ability to come to grips with the complexity of systems development and the organizations within which they are embedded, an interpretivist analysis of ISD has enjoyed increasing popularity. Here, the focus is on the interpretations of actors and how these actors socially construct organizations and information systems. The process of systems development involves sense-making of the social interaction among various actors, 
resulting in consensus and a set of agreed objectives. With this perspective, we witness a shift in focus from technical development to interpretation of social action. The role of the systems developer is that of facilitator (Hirschheim and Klein 1989), working alongside users in order to assist them in articulating their preferred views. Hence, this stream of research is often associated with the emergence of a number of development approaches that are concerned with the socio-tecnnical fit (ETHICs-Mumford 1983) or understanding problem construction from multiple perspectives (e.g., soft systems methodology-Checkland 1981). Such approaches favor strong user participation, allowing a system to emerge based upon what the social actors construct as being a good system, although problems with these approaches have been widely reported (Franz and Robey 1984; Howcroft and Wilson 2003; Newman 1989). Interpretivist research has helped advance IS research and offers an alternative to the positivist orthodoxy, but, like its positivist counterparts, interpretivism is also reliant upon a "regulation theory of society" (Burrell and Morgan 1979), which lacks analysis of the relations of power and control that regulate and legitimize socially constructed meanings. In this respect, interpretivism often neglects to analyze many aspects of context, such as the dominance of one social interest or single economic imperative, that shape organizational form and processes.

In contrast, critical research on ISD is more reflective in that it considers organizations and information systems in their wider social context, attending to issues such as power, domination, conflict, and contradiction. Actors within ISD are affected both by wider macro-socio-economic forces that constrain their opportunities and scope, and by factors that shape their everyday interactions within their local organizations. In this respect, ISD takes place within a complex network of structures, with the developer often placed in an oppositional role faced with the opposing interests of both management and end-users. Arguably, the Scandinavian tradition has helped to lay the foundations for a more critically informed approach to IS development and use, enabling other researchers to tread along a similar path. Scandinavian research projects operate within a different paradigm from the contemporary North American MIS tradition (Iivari and Lyytinen 1998) in that they subscribe to the notion of increasing workplace democracy, the intention being that all employees should have influence over their work situation and participate in decision-making forums (Bjerknes and Bratteteig 1995). In the late 1960s, a number of experimental projects consisting of trade union and employer organizations focused on the goals of job satisfaction and higher productivity (Ehn 1988). However, many of these projects faced severe difficulties during systems implementation as the differing interests of management and employees were evidently irreconcilable. Indeed, Scandinavian and British participatory projects were criticized at the time by Marxist theorists in Scandinavia for promoting fundamentally capitalist values; that is, increasing productivity and curtailing worker resistance (Asaro 2000, p. 268). Over time, the notion of joint decision making and worker influence has virtually disappeared (Kyng 1998) and it appears that the socio-technical approach "was a product of a particular socio-political regime" (Avgerou 2002, p. 55) that was popular during times of labor shortages when efforts were made to retain employees. Nevertheless, the Scandinavian tradition, particularly with regard to its attitude toward participatory practices, has had considerable influence in the IS literature and has contributed to the legitimization of ISD as a political project. 
Critical information systems research overcomes the limitations of positivist research, with its rejection of the unitary model of organizations and the technologically determinist view of information technology. It also overcomes some of the weaknesses of the interpretivist approach by calling upon greater contextual awareness that may help explain why certain interpretations (rather than others) dominate and are seen to represent organizational reality. As mentioned, much of the critical information systems research that is concerned with ISD draws upon the Habermasian perspective, striving for emancipation through free and undistorted communication, yet how the emancipatory ideal may be applied in the context of ISD is "very much in the making with no examples or strict methodologies available" (Alvesson and Willmott 1996). For this research area to advance, practical examples would certainly add credibility.

\subsection{Critical Examination of Gender and Information Technology}

While the previous discussion considered the application of critical IS research to information system development and use, this section considers the application of critical IS research to the users of information systems and technology. Specifically, it considers the use of critical IS research to examine power relations and under represented voices in the context of gender and IT use. This example was chosen because the issues involved in this topic are consistent with the themes represented in critical research that were discussed in section 2 .

When the positivist epistemology is applied to the topic of gender and IT, the objective is typically to discover whether and where there are gender differences-in women's vs. men's use (adoption, acceptance, etc.) of IT (e.g., Gefen and Straub 1997) or in women's participation rate in the IS profession (e.g., Carayon et al. 2003; Truman and Baroudi 1994). Further, the theory underlying positivist gender research is often essentialism. That is, observed gender differences are understood to arise from the dichotomizing of male/ female roles that, in turn, are assumed to derive from biopsychological differences (Wajcman 1991). The motivation for conducting this research is generally to advance managerial objectives. For example, it might be to consider gender as a factor of production in better harnessing diversity in pursuit of effectiveness and productivity (e.g., Gallivan 2003; Igbaria and Baroudi 1995; Igbaria and Chidambaram 1997; Venkatesh and Morris 2000). Problems of inequalities are seen in terms of wasted resources, and increased equality is promoted in the hope of optimizing efficiency.

The main criticisms of this approach to studying the topic of gender and IT relate to the scope and the particular point of view that becomes privileged in the research. Positivist investigations of gender and IT remain on the surface of observable and documentable differences. In so doing, they are vulnerable to charges of superficial and unproblematic treatment of the topic. Further, by offering only managerialist perspectives, positivist gender and IT research privileges one perspective over others. Hence, the gendered aspects of IT use are not considered from the perspective of those experiencing it.

These limitations are addressed in interpretive studies of gender and IT use. Research that employs the interpretive lens to examine this topic focuses on developing 
a better understanding of how these gender differences in IT use have come about. The objective is to add context to the observations about the relationship between gender and IT. Thus, this research is more likely to invoke theories of social construction or individual differences (Trauth 2002) in developing theoretical explanations for gender differences. The motivation is to better understand the social influences underlying inequality (i.e., observable differences) between the genders. While some of this research privileges managerialist goals, not all of it does. Some interpretive gender and IT research desires to advance our understanding of the relationship between gender and IT from the point of view of women IT users. Thus, an interpretive examination of gender and the IS profession might explore the influence of national culture on the social construction of gender identity as it relates to the IT workforce (Trauth 1995; Trauth et. al 2003). However, a criticism of the interpretive approach is that the focus is on understanding the societal influences, not questioning them. It is directed at coping with the dynamics of inequality, not questioning the legitimacy of underlying social influences or changing them.

In contrast, the objective of critical research about gender and IT is to advocate a position as to why gender inequality exists. In doing so, it challenges the status quo and the dominant discourses about gender and IT. Critical social theory, postmodernism, and feminist theory (Adam 2002; Adam and Richardson 2001), for example, are used to inform the search for the underlying causes of gender inequality. Thus, this approach to gender and IT research moves away from traditional themes found in positivist and interpretive gender research such as profitability, efficiency, effectiveness, and gender identity. Instead, it focuses on concepts such as power, control, resistance, and inequality. The motivation for this research is more activist than positivist or interpretive research: to challenge power relations that reproduce inequality. Thus, a critical perspective on gender and IT might concentrate on the gendered nature of the workplace and technological skills (e.g., Adam and Richardson 2001; Wilson 2002). However, a criticism that could be made of critical gender and IT research is that the research itself is subject to power relations and dominant discourses.

The use of critical IS research to study this topic addresses the limitations of both positivist and interpretive research on gender and IT. In doing so, alternative explanations and theories become available. Critical information systems overcomes positivist limitations by offering alternatives to a managerialist perspective and managerialist theories. It goes beyond interpretive understanding of societal influences to explore power relations, marginality, and dominant discourses in the organizational and societal context. While critical information systems research regarding gender and IT opens up new avenues for exploring the topic of gender and IT, it also brings with it issues and challenges that could be limiting factors. These issues are addressed in the next section.

\section{IMPLICATIONS FOR IS RESEARCH AND PRACTICE}

Consistent with a critical stance on IS research, we now apply a critical lens to critical IS research. In doing so, we raise issues regarding the use of critical research to examine the relationship between information systems and the organizations or societies 
within which they are embedded. We then offer some challenges and recommendations to the IS community regarding the conduct of critical information systems research.

\subsection{Issues with the Choice of Critical Research}

We begin with a consideration of issues that arise from the choice of a critical approach to the study of IS topics. Using a framework that was developed to assess the choice of qualitative research (Trauth 2001), we consider theoretical, methodological, and political issues associated with the choice of critical IS research.

One theoretical issue is the need for greater theoretical diversity. As noted earlier in this paper, the thrust of critical IS research to date has been in the Habermasian tradition. As Adam (2002) pointed out in her argument for exploring emancipation through feminist theory, broadening the theoretical base of critical IS research will yield both epistemological and practical benefits. Another theoretical issue is that in order to dojustice to a critical approach, IS research requires levels of analysis that go beyond the organizational level. In order to better understand the interplay of the social and the technical, we need to expand our level of understanding to include other elements such as macro-economic, societal, cultural, and industry-specific factors.

A range of methodological issues emanate from the decision to conduct critical research. One is whether there are any methodological principles that are specific to this kind of research or whether one can simply use any methodology suitable for the study of IS in general. This issue is discussed in section 4.2 below. A second issue, with notable exceptions such as Klecun-Dabrowska (2002), Kvasny (2002) and Richardson (2003), is the dearth of empirical studies. However, when empirical critical IS research is conducted, other issues arise. One set of issues relates to the research subject and data collection. It can be very problematic to elicit the kinds of data that further a critical investigation of the topic. For example, in the researcher's effort to elicit comments from the participant about emancipation, she or he might be encouraging the participant to verbalize comments about personally painful experiences or organizationally inappropriate behavior that the participant might prefer not to confront. But if the researcher is successful in bringing these experiences into the participant's consciousness, another issue arises: coping with the aftermath of this consciousness raising. At the end of the interview session, the researcher walks away but the subject may undergo a personal transformation because of the interview experience. In its mildest form, the participants may have a new awareness about issues in their personal or organizational lives. In some circumstances, however, the transformation the subjects experience might be psychologically or emotionally traumatic. The challenge for the researcher has both methodological and ethical dimensions.

Another set of methodological issues relates to data analysis. If interpretive research must overcome the charge ofbias, the challenge for critical research is even greater. The reduction of bias is given much attention by positivists, since it is assumed that such a reduction will move one closer to the truth. Another perspective is that all research is inherently biased and that the only difference is that the critical researcher is more likely to acknowledge (or even defend) their explicit bias. Given the dominant discourse, how does one cope with the charge of bias when the research epistemology consciously 
adopts a particular stance (i.e., in favor of emancipation and in critique of tradition and technological determinism) in interpreting the data?

Political issues are deeply embedded in critical research. Since one of the objectives is to critique the status quo, the vested interests of the dominant discourse can be threatened. For example, critical IS research that adopts perspectives other than managerial and is interested in understanding why some problem or situation occurs from alternative points of view can pose a serious challenge to journals and academic departments whose publishing norms and reward systems are limited to a managerialist (i.e., a management information system) perspective on IS problems. A second political issue is that the search for relevant social theories may result in ones that are new to the IS community, the journals, and the reviewers. Further, they may even contradict current theories-in-use.

\subsection{Challenges and Recommendations for the Conduct of Critical IS Research}

When considering the conduct of critical IS research studies, one might assume that qualitative techniques would seem the most appropriate choice. Drawing a battle line between questions oftechnique can be misleading since it detracts from the more central problem of how we choose to interpret and represent social reality. Of greater concern is the issue ofbeing reflective about the social and organizational underpinnings ofone's own recommendations and practices. As noted elsewhere,

Method is thus not primarily a matter of "data management" or the mechanics and logistics of data production/processing, but is a reflexive activity where empirical material calls for careful interpretation-a process in which the theoretical, political and ethical issues are central (Alvesson and Skoldberg 2000, p. 5).

The central premise of critical research is the balance between being informed by critical theoretical ideas and a political agenda, and maintaining an empirical sensitivity toward and interest in the discovery of repression. Having too much of a theoretical focus can lead to intellectual elitism and insensitivity to the richness ofempirical settings and the lived experience of people at "the front line." Having too much empirical work can lead to a narrow focus which ignores the macro, economic, and social context, and becomes engrossed in surface phenomena, thus losing the critical edge. In an attempt to show how we can strive to achieve this balance, we draw on the work of Alvesson and Deetz (2000) in offering some guidelines on the conduct of critical research. Three overlapping tasks that the critical researcher may wish to consider are insight, critique, and transformative redefinition.

\subsubsection{Insight}

Insight refers to understanding how various forms of knowledge, objects, and events are formed and sustained, highlighting hidden or less obvious aspens of social reality. 
The task here is to investigate at a local level and then relate these empirical themes to wider economic, social, historical, and political forces. Insight is about the process of producing meaning from the data, and understanding the conditions (e.g., socioeconomic context) which frame how we make sense of the data. This serves as an important reminder of the value of engaging with organizational practices and people within them as our subject of interest. Indeed, one of the greatest criticisms leveled at critical research is the lack of extended empirical studies (Alvesson and Deetz 2000; Alvesson and Willmort 1996; Boudreau 1997).

Critical theory and postmodemism's strong critique of empiricism does not mean that reflective empirical work is not a worthwhile activity. To ground theories of bureaucracy, capitalism, managerialism, and technological determinism in organizational contexts and the lives oforganizational members can only aid our understanding of these issues. At the same time, we should be attendant to some of the difficulties of empirical work. For critical studies, the metaphor of researcher as mirror is replaced by lens noting the role of the researcher as positioned and active (Alvesson and Deetz 2000). An example of this can be found in the work of Richardson (2003), who used the work of Bourdieu (1990) in her analysis of call center workers in the UK to highlight significant contradictions between system objectives and outcomes in practice. The paper throws the spotlight on the individuals working at the call center front line and tells stories often left untold in studies of IS adoption and use.

For critical research, the focus is on the ability to challenge guiding assumptions, values, social practices, and routines of an observation. Rather than seeing the world from the native's point of view by viewing events, actions, and values from the perspective of the people being studied, critical researchers aim to balance their interest in the level of meaning, with an awareness of less explicit ideological and structural forces (see, for example, Lukes 1974). This is in contrast to what Bhaskar (1979) has described as the "linguistic fallacy," the claim adopted by many interpretivists that subjects, concepts, meanings, and accounts of their actions cannot be criticized. This fallacy is based on the assumption that reality is expressed in the language of social actors. The experiences of the subjects of study are neither the primary nor the only focus of interest. The lens shifts from exclusive focus on individuals, situations, and meaning to the systems of relations, which make such meanings possible. This is not to suggest that experiences should be ignored; rather, they must be balanced with attendance to issues of an ideological nature that may frame the experiences and prescribe meaning. This enables researchers to deal with the conditions which give rise to the meaning and interpretations of social actors, an element that is often absent in much interpretivist research (Fay 1975). Ultimately, insight can lead to the production of competing discourses and even counter-discourses.

\subsubsection{Critique}

Critique challenges many of the assumptions, beliefs, ideologies, and discourses that permeate IS phenomena. Political, economic, and social forces are inscribed in organizational arrangements (Alvesson and Willmott 1996) and technological artefacts (Akrich 1992; Winner 1985). To assume that this is natural or represents the one best way is insufficient, since these phenomena arise as a result of ideological and historical forces 
that privilege certain groups. Addressing this privileging of certain discourses and constructions is, therefore, a crucial aspect of critical research. Whereas insight focuses on local specifics, with critique the lens shifts to general characterizations relating to wider social concerns and often the larger global community. Critique explicitly relates to power constraints, repression, ideology, social asymmetries, and technological determinism that give priority to certain ways of viewing the world. If we were to study IS phenomena at the micro, meso, and macro levels (Drummond 1996), it may provide us with a deeper understanding of information systems. Doing so would entail examining the process of systems development and use, and their relationship to organizational context. These, in turn, reflect and reproduce the major social inequalities in society (Knights and Murray 1997). At the macro level, understanding such issues as managerial and labor processes and IT markets could provide further understanding of information systems at the organizational level. An example of such work includes research by Klecun-Dabrowska (2002), who applied a critical perspective to telehealth in the UK. Klecun-Dabrowska examined the historical conditions and structures that shape telehealth, including the organization of health care in Britain, the health policy process, strategies for the employment of ICTs, and visions of an information society.

\subsubsection{Transformative Redefinition}

A third task refers to the development of critical, relevant knowledge and practical understandings that facilitate change. In this respect, the third element is the most difficult. While it is important that critical information systems researchers aim to disrupt the dominant ethos in mainstream literature, there are problems with building a research stream that is based only on critique and negation, but does not put anything forward. Research that is perceived as anti-technology and anti-management will have limited appeal and adds little toward the goal of social change. Even though critical researchers seek to avoid telling people what to do, transformative redefinition aims to suggest an alternative and radically different view of the world, which emphasizes change but in a more positive way. This is difficult to achieve as efforts to progress things forward (such as the attempt by Deetz [2003] to overcome the problems of workplace communication in the hope of improving collaborative decision-making) run the risk of co-optation. The challenge of smoothing over irreconcilable differences could result in exemplification of what we initially set out to criticize. Co-optation is best avoided by careful consideration of who one chooses to be involved with within the organization, rather than merely espousing Utopian ideals.

In terms of transformative redefinition, perhaps here we can draw on some of the discussions that have taken place within CMS concerning the different perspectives on our role as educators (see Grey and Mitev 1995). This breaks down essentially into two opposing positions. On the one hand, there is the militant position, which is committed to the victims of corporate power and leverages our role as academics in the form of "hell raising and muckraking" (Adler 2002). This position is one of complete disengagement with management practice, where the task is not to reform management but to undermine it and expose it through critique. The other position is that of humanist, which is based on a respectful engagement with students, based on the premise that managers are people too. It aims to develop, promote, and transform more humane forms 
of management by engaging in a dialogue with management practitioners in the hope that they could become potential allies in the future (e.g., Alvesson and Willmott 1996). As IS researchers, many of us are engaged in the teaching of students and thus have the potential for considerable influence. Given that our voices have an element of legitimacy with students, by encouraging and enabling them to question many of the prevailing assumptions within our field (such as an acceptance of organizational hierarchy, managerialism, globalization, the primacy of markets, and technological determinism), a more mature understanding may arise that emerges as a refreshing antithesis to the orthodoxy.

This issue clearly links in with the notion in IS research of research for whom that asks the question who is our target audience? This is a highly contentious and lengthy debate $^{1}$ centered on the issue ofthe relevance of our research. When IS research exposes inappropriate and unjust work and power relations that practitioners are unwilling to accept, this does not imply that such research is not relevant (Lee 1999). The problem of relevance (or engagement) is that the debate has been conducted in a one-sided way and is centered on the assumption that we should engage with (IT) practitioner managers and the interests of business, rather than concern ourselves with the managed-the people lower down the organizational hierarchy who are on the receiving end of managerial practice. If we are to be critical in terms of local action and practice, then consideration should be given to those with whom we choose to engage. As pointed out elsewhere (Truex 2001), less powerful groups such as trade unions or community groups should also have access to the skills and insights that we have to offer. As researchers, we can choose whether we want to give advice to management or to people who are on the receiving end of management decisions. Relevance is not only about whether or not we engage in a dialogue with management, but also about whether or not we choose to broaden our focus of study to include a much more inclusive organizational constituency. Perhaps we need to consider the possibility of telling different stories.

As critical researchers, our role in transformative definition can also extend beyond the local environment to broader issues relating to the publication of our work. Critically oriented publications in both academically oriented and practitioner-oriented outlets can reach a broad audience while simultaneously challenging the status quo and critiquing many taken-for-granted assumptions regarding technology and organizations. Publications of this nature can generate additional insights into recurring problems such as information systems failures, the conflictual nature of user-developer relations, or the productivity paradox. While publications of this nature cannot solve such problems, the insights that arise from this can be enlightening and potentiality transformative. They can at least contribute to a greater understanding of the nature of organizational relations and avoid the scapegoating of people and technologies that fail to live up to expectations

\section{CONCLUSION}

The purpose of this paper is to address the themes of both this conference and the 1984 IFIP WG 8.2 conference to "think carefully about the organizational and societal consequences of the systems they are developing and using" (see the Call for Papers for

\footnotetext{
${ }^{1}$ See Lee (1999) for an overview.
} 
this conference). This has been accomplished by considering the research approaches by which we examine and assess the ways in which information systems are used by and affect people. We employ critical IS research methods to carry out this assessment. In the course of examining research approaches, we also address another theme of this conference: concern with the ability of traditional research methods to adequately address these organizational and societal dimensions. In 1984, traditional would have been understood to be quantitative, positivist studies; in 2004 the definition of traditional can, arguably, be broadened to include qualitative, interpretive studies. In our consideration of critical IS research we revisit this theme of methodological limitations by illustrating the benefits of broadening the definition even further to include critical research as one of the mainstream IS research methods.

This paper also contributes to the broader IS research community in two ways. First, it can serve as a useful resource for people trying to understand critical IS. Second, it contributes to the development of a distinct, critical IS research literature. There is little in the general critical literature that differentiates critical IS research from other critical arenas; we are provided with insights about emancipation, for example, but with no mention of technological determinism. In terms of social theory, technology is an offstage phenomenon, that has not been seriously integrated (Sorensen 2002) and the field of sociology has never steadfastly nurtured an interest in technology (Button 1992). Given the nature of the IS field and our object of study, we need suitable ways of conceptualizing how we integrate the material (technology) into the analysis of human societies. Critical IS can provide a way of helping with this conceptualization.

\section{REFERENCES}

Adam, A., and Richardson, H. "Feminist Philosophy and Information Systems," Information System Frontiers (3:2), 2001, pp. 143-154.

Adler, P. "Critical in the Name of Whom and What?," Organization (9:3), 2002, pp. 387-395.

Akrich, M. "The De-scription of Technical Objects," in W. E. Bijker and J. Law (Eds.), Shaping Technology/Building Society: Studies in Sociotechnical Change, Cambridge, MA: MIT Press, 1992.

Alvesson, M., and Deetz, S. Doing Critical Management Research, London: Sage Publications, 2000.

Alvesson, M., and Skoldberg, K. Reflexive Methodology, London: Sage Publications, 2000.

Alvesson, M., and Willmott, H. "On the Idea of Emancipation in Management and Organization Studies," Academy of Management Review (17:3), 1992, pp. 432-464.

Alvesson, M., and Willmott, H. Making Sense of Management: A Critical Introduction, London: Sage Publications, 1996.

Avgerou, C. Information Systems and Global Diversity, Oxford: Oxford University Press, 2002.

Asaro, P. "Transforming Society by Transforming Technology: The Science and Politics of Participatory Design," Accounting, Management and Information (10), 2000, pp. 257-290.

Beath, C. M., and Orlikowski, W. J. "The Contradictory Structure of Systems Development Methodologies: Deconstructing the IS-User Relationship in Information Engineering," Information Systems Research (5:4), 1994, pp. 350-77.

Bhaskar, R. The Possibility of Naturalism: A Philosophical Critique of the Contemporary Human Sciences, Brighton, UK: Harvester, 1979.

Bijker, W. E. "Sociohistorical Technology Studies," in T. Pinch (Ed.), Handbook of Science and Technology Studies, Thousand Oaks, CA: Sage Publications, 1995, pp. 229-256. 
Bjerknes, G., and Bratteteig, T. "User Participation and Democracy: A Discussion of Scandinavian Research on System Development," Scandinavian Journal of Information Systems (7:1), 1995, pp. 73-98.

Boland, R. J., and Pondy, L. R. "Accounting in Organizations: A Union of Natural and Rational Perspectives," Accounting, Organizations and Society (8), 1983, pp. 223-234.

Bourdieu, P. The Logic of Practice, Cambridge, MA: Polity Press, 1990.

Brooke, C. "Critical Perspectives on Information Systems: An Impression of the Landscape," Journal of Information Technology (17), 2002a, pp. 271-283.

Brooke, C. "Editorial: Critical Research in Information Systems," Journal of Information Technology (17), 2002b, pp. 45-47.

Burrell, G., and Morgan, G. Sociological Paradigms and Organizational Analysis, London: Heinemann, 1979.

Button, G. "The Curious Case of the Vanishing Technology," in G. Button (Ed.), Technology in Working Order: Studies of Work, Interaction and Technology, London: Routledge, 1992.

Carayon, P.; Hoonakker, P.; Marchland, S.; and Schwarz., J. "Job Characteristics and Quality of Working Life in the IT Workforce: The Role of Gender," in E. Trauth (Ed.), Proceedings of the 2003 SIGMIS Conference on Freedom in Philadelphia: Levering Differences and Diversity in IT, New York: ACM Press, 2003, pp. 58-63.

Cecez-Kecmanovic, D. "Doing Critical IS Research: The Question of Methodology," in E. M. Trauth (Ed.), Qualitative Research in IS: Issues and Trends, Hershey, PA: Idea Group Publishing, 2001, pp. 141-163.

Cecez-Kecmanovic, D.; Moodie, D.; Busuttil, A.; and Plesman, F. "Organizational Change Mediated by E-Mail and Intranet: An Ethnographic Study," Information Technology and People (12:1), 1999, pp. 9-26.

Checkland, P. B. Systems Thinking, Systems Practice, Chichester, England: John Wiley \& Sons, 1981.

Deetz, S. "Developing Critical Communication Theories for Collaboration: Using Workplace Participation as an Example," in Proceedings of Critical Management Studies 3, Lancaster, UK, 2003 (available online athttp://www.mngt.waikato.ac.nz/research/ejrot/cmsconference/ 2003/abstracts/abstracts_communication.asp; accessed December 2003).

Doolin, B. "Information Technology as Disciplinary Technology: Being Critical in Interpretive Research on Information Systems," Journal of Information Technology (13), 1998, pp. 301311.

Doolin, B., and Lowe, A. "To Reveal Is to Critique: Actor-Network Theory and Critical Information Systems Research," Journal of Information Technology (17), 2002, pp. 69-78.

Dooyeweerd, H. “Introduction,” Philosophia Reformata (38), 1973, pp. 5-16.

Drummond, H. Escalation in Decision-Making: The Tragedy of Taurus, Oxford: Oxford University Press, 1996.

Ehn, P. Work-Oriented Design of Computer Artefacts, Stockholm: Arbeslivscentrum, 1988.

Fay, B. Social Theory and Political Practice, London: Allen \&Unwin, 1975.

Forester, J. "Critical Ethnography: On Fieldwork in a Habermasian Way," in M. Alvesson and H. Willmott (Eds.), Critical Management Studies, London: Sage Publications, 1992.

Foucault, M. Discipline and Punish: The Birth of the Prison, Harmondsworth, England: Penguin, 1979.

Fournier, V., and Grey, C. "At the Critical Moment: Conditions and Prospects for Critical Management Studies," Human Relations (53:1), 2000, pp. 7-32.

Franz, C. R., and Robey, D. "An Investigation of User-Led Systems Design: Rational and Political Perspectives," Communications of the ACM (27:12), 1984, pp. 1202-1209.

Gallivan, M. "Examining Gender Differences in IT Professionals' Perceptions of Job Stress in Response to Technological Change," in E. Trauth (Ed.), Proceedings of the ACM SIGMIS CPR Conference, New York: ACM Press, 2003, pp. 10-23. 
Gefen, D., and Straub, D. W. "Gender Differences in the Perception and Use of E-Mail: An Extension to the Technology Acceptance Model," MIS Quarterly (21:4), 1997, pp. 389-400.

Grey, C., and Mitev, N. "Management Education: A Polemic," Management Learning (26:1), 1995, pp. 73-90.

Hammersley, M. The Politics of Social Research, London: Sage Publications, 1995.

Heidegger, M. Being and Time, New York: State University of New York Press, 1953.

Hirschheim, R., and Klein, H. K. "Four Paradigms of Information Systems Development," Communications of the ACM (32:10), 1989, pp. 1199-1216.

Hirschheim, R., and Klein, H. K. "Realizing Emancipatory Principles in Information Systems Development: The Case for ETHICS," MIS Quarterly (18:1), 1994, pp. 83-109.

Horkheimer, M. "Traditional and Critical Theory (1937)," in P. Connerton (Ed.), Critical Sociology. Harmondsworth, England: Penguin, 1976.

Howcroft, D., and Wilson, M. "Paradoxes of Participatory Design: The End-User Perspective," Information \& Organization (13:1), 2003, pp. 1-24.

Igbaria, M., and Baroudi, J. J. "The Impact of Job Performance Evaluations on Career Development Prospects: An Examination of Gender Differences in the IS Workplace," MIS Quarterly (19:1), 1995, pp. 107-123.

Igbaria, M., and Chidambaram, M. "The Impact of Gender on Career Success of Information Systems Professionals," Information Technology \& People (10:1), 1997, pp. 63-86.

Iivari, J., and Lyytinen, K. "Research on Information Systems Development in Scandinavia: Unity in Plurality," Scandinavian Journal of Information Systems (10:1/2), 1998, pp. 135185.

Klecun-Dabrowska, E. Telehealth and Information Society: A Critical Study of Emerging Concepts in Policy and Practice, Unpublished Ph.D. Thesis, Department of Information Systems, London School of Economics and Political Science, 2002.

Klein, H. K., and Hirschheim, R. "The Application of Neohumanist Principles in Information Systems Development," in D. Avison, J. E. Kendall, and J. I. DeGross (Eds.), Human, Organizational and Social Dimensions of Information Systems Development, Amsterdam: North Holland, 1993, pp. 263-279.

Knights, D., and Murray, F. "Markets, Managers and Messages: Managing Information Systems in Financial Services,” in B. Bloomfield, R. Coombs, D. Knights, and D. Littler (Eds.), Information Technology and Organizations: Strategies, Networks andIntegration, Oxford: Oxford University Press, 1997, pp. 36-56.

Kvasny, L. Problematizing the Digital Divide: Cultural and Social Reproduction in a Community Technology Initiative, Unpublished Ph.D. Thesis, Department of Computer Systems, Robinson College of Business, Georgia State University, 2002.

Kyng, M. "Users and Computers: A Contextual Approach to Design of Computer Artifacts," Scandinavian Journal of Information Systems (10:1/2), 1998, pp. 7-44.

Latour, B. "Technology Is Society Made Durable," in J. Law (Ed.), A Sociology of Monsters: Essays on Power, Technology and Domination, London: Routledge, 1991, pp. 103-131.

Lee, A. S. "Rigor and Relevance in MIS Research: Beyond the Approach of Positivism Alone," MS Quarterly (23:1), 1999, pp. 29-34.

Lukes, S. Power: A Radical View, London: MacMillan, 1974.

Lyytinen, K. "Information Systems and Critical Theory," in M. Alvesson and H. Willmott (Eds.), Critical Management Studies, London: Sage Publications, 1992.

Lyytinen, K., and Hirschheim, R. "Information Systems and Emancipation: Promise or Threat?," in H. Klein and K. Kumar (Eds.), Systems Development for Human Progress, Amsterdam: North Holland, 1989, pp. 115-139.

Lyytinen, K., and Hirschheim, R. "Information Systems as Rational Discourse: An Application of Habermas's Theory of Communicative Action," Scandinavian Journal of Information Systems (4:1/2), 1988, pp. 19-30. 
Lyytinen, K., and Klein, H. K. "The Critical Theory of Jurgen Harbermas as a Basis for a Theory of Information Systems," in E. Mumford, R. Hirschheim, G. Fitzgerald, and A. T. WoodHarper (Eds.), Research Methods in Information Systems, Amsterdam: North Holland, 1985, pp. 219-236.

Markus, M. L. "Power, Politics, and MIS Implementation," Communications of the ACM (26:6), 1983, pp. 430-444.

Marx, K. Capital, London: Penguin, 1974.

Mingers, J. "Technical, Practical and Critical OR: Past, Present and Future?" in M. Alvesson and H. Willmott (Eds.), Critical Management Studies, London: Sage Publications, 1992, pp. 90-112.

Mingers, J. "What Is it to Be Critical? Teaching a Critical Approach to Management Undergraduates," Management Learning (31:2), 2000, pp. 219-237.

Mumford, E. Designing Human Systems: The ETHICS Method," Manchester Business School, Manchester, England, 1983.

Myers, M. D., and Avison, D. E. Qualitative Research in Information Systems: A Reader, London: Sage Publications, 2002.

Newman, M. "Some Fallacies in Information Systems Development," International Journal of Information Management (9), 1989, pp. 127-143.

Ngwenyama, O. K. "The Critical Social Theory Approach to Information Systems: Problems and Challenges," in H-E. Nissen, H. K. Klein, and R. Hirschheim (Eds.), Information Systems Research: Contemporary Approaches and Emergent Traditions, Amsterdam: North-Holland, 1991, pp. 267-280.

Ngwenyama, O. K., and Lee, A. S. "Communication Richness in Electronic Mail: Critical Social Theory and the Contextuality of Meaning," MIS Quarterly (21:2), 1997, pp. 145-167.

Orlikowski, W. J., and Baroudi, J. J. "Studying IT in Organizations: Research Approaches and Assumptions," Information Systems Research (2:1), 1991, pp. 1-28.

Richardson, H. "CRM in Call Centres: The Logic of Practice," in M. Korpela, R. Montealegre, and A. Poulymenakou (Ed.), Organizational Information Systems in the Context of Globalization, Boston: Kluwer Academic Publishers, 2003, pp. 69-84.

Russell, S., and Williams, R. "Social Shaping of Technology: Frameworks, Findings and Implications for Policy with Glossary of Social Shaping Concepts," in R. Williams (Ed.), Shaping Technology, Guiding Policy: Concepts, Spaces and Tools, Cheltenham, UK: Edward Elgar, 2002, pp. 37-132.

Sorensen, K. "Social Shaping on the Move? On the Policy Relevance of the Social Shaping of Technology Perspective," in R. Williams (Ed.), Shaping Technology, Guiding Policy: Concepts, Spaces and Tools, Cheltenham, UK: Edward Elgar, 2002, pp. 19-35.

Trauth, E. "Odd Girl Out: An Individual Differences Perspective on Women in the IT Profession," Information Technology \& People (15:2), 2002, pp. 98-118.

Trauth, E. (Ed.). Qualitative Research in IS: Issues and Trends, Hershey, PA: Idea Group Publishing, 2001.

Trauth, E. "Women in Ireland's Information Industry: Voices from Inside," Eire-Ireland (30:3), 1995, pp. 133-150.

Trauth, E., and Jessup, L. "Understanding Computer-Mediated Discussions: Positivist and Interpretive Analyses of Group Support System Use,” MIS Quarterly (24:1), 2000, pp. 43-79.

Trauth, E., Nielsen, S.; and von Hellens, L. "Explaining the IT Gender Gap: Australian Stories for the New Millennium," Journal of Research and Practice in Information Technology (35:1), 2003, pp. 7-20.

Truex, D. P. "Three Issues Concerning Relevance in IS Research: Epistemology, Audience and Method, Communication of the AIS, 2001.

Truman, G. E., and Baroudi, J. J. "Gender Differences in the Information Systems Managerial Ranks: An Assessment of Potential Discriminatory Practices," MIS Quarterly (18:2), 1994, pp. 129-141. 
Venkatesh, V., and Morris, M. "Why Don't Men Ever Stop to Ask for Directions? Gender, Social Influence, and Their Role in Technology Acceptance and Usage Behavior," MIS Quarterly (24:1), 2000, pp. 115-139.

Wajcman, J. Feminism Confronts Technology, Cambridge, MA: Polity Press, 1991.

Williams, R., and Edge, D. "The Social Shaping of Technology," Research Policy (2), 1996, pp. 865-899.

Wilson, M. "Making Nursing Visible? Gender, Technology and the Care Plan as Script," Information Technology \& People (15:2), 2002, pp. 139-158.

Winner, L. "Do Artifacts have Politics?," in D. MacKenzie and J. Wajcman (Eds.), The Social Shaping of Technology, Buckingham, England: Open University Press, 1985, pp. 26-38.

\section{ABOUT THE AUTHORS}

Debra Howcroft is a senior lecturer in information systems at Manchester School of Accounting and Finance, the University of Manchester. Her research interests focus upon the social and organizational aspects of information systems. For more information, visit Debra's website at http://man.ac.uk/accounting/Staff/Academic/D_Howcroft.htm. She can be reached at debra.a.howcroft@man.ac.uk.

Eileen M. Trauth is a professor of Information Sciences and Technology and Director of the Center for the Information Society at The Pennsylvania State University. She received her $\mathrm{Ph} . \mathrm{D}$. in information science from the University of Pittsburgh. Her current research interest is the influence of socio-cultural factors and public policy on the development of information economies. Eileen has conducted extensive research into Ireland's information economy as a Fulbright Scholar, and was the recipient of an Irish Science Foundation Walton Visitor Award in 2003. Eileen is also the recipient of an NSF IT Workforce grant to investigate the underrepresentation of women in the American IT labor force. She is the author of The Culture of an Information Economy: Influences and Impacts in the Republic of Ireland (Kluwer, 2000), coauthor of Information Literacy: An Introduction to Information Systems (Macmillan, 1991), editor of Qualitative Research in IS: Issues and Trends (Idea Group Publishing, 2001) and coeditor of Seeking Success in E-Business: A Multidisciplinary Approach (Kluwer, 2003). Eileen has conducted cross-cultural research in Europe and Australia and has published articles on sociocultural and organizational influences on IT, qualitative research methods, global informatics, information policy, information management, and the development of IS professionals. She serves on the editorial boards of several international journals. 